\title{
Perilaku Berpantang Makan pada Ibu Hamil Suku Dayak di Kabupaten Sintang Kalimantan Barat
}

\author{
Siti Nurul Huda*, Martha Irene Kartasurya**, Sulistiyani** \\ *AKPER Pemprov Kalimantan Barat \\ ** Fakultas Kesehatan Masyarakat Universitas Diponegoro, Semarang \\ Email: 5171nadyra@,gmail.com
}

\section{ABSTRACT}

Each region has a specific diet, especially for pregnant women, accompanied by a belief in taboos and a ban on certain foods. The purpose of this study was to identify and analyse food taboo of pregnant women in Dayak Ethnic in Sintang, West Borneo.

This was qualitative study conducted on 5 pregnant women who practiced food taboo as the main informants. Two other informants were the mother who stayed in the same homes and one traditional birth attendance as the triangulation informants. The were sampling chosen purposively. Data collection were conducted through in-depth interview. Data analysis was done in content analysis.

The source of food which were abstinenced by pregnant mothers were grouped into source of staple food, side dishes, vegetable and fruit. The reasons of food taboo were the bad/negative impact for the mom's and babies health. The proponents for food taboo were the mothers, mother in-laws, husbands, and the is closest family. Its food taboo were still practiced by pregnant women and the most common food were fish. In order improving IEC (Counseling, Information and Education) for closest family of pregnant women about the importance of balanced nutrition and a good diet for pregnant women to change wrong perceptions about food taboo during pregnancy.

Keywords: Food Taboos, Pregnant Women.

\section{PENDAHULUAN}

Gizi yang seimbang sangat penting dan dibutuhkan bagi ibu hamil, karena disepanjang kehamilan kebutuhan akan zat gizi terus mengalami peningkatan yang akan digunakan untuk pertumbuhan dan perkembangan janin. ${ }^{1}$ Kekurangan akan zat gizi selama masa kehamilan tidak hanya berdampak pada masa kehamilan saja seperti anemia dan Kekurangan Energi Kronis (KEK), namun juga berdampak pada masa persalinan dan nifas, serta pada janin atau bayi. ${ }^{2}$

Setiap daerah mempunyai pola makan tertentu khususnya pada ibu hamil yang disertai dengan kepercayaan akan pantangan, tabu, dan larangan terhadap beberapa makanan tertentu. ${ }^{3}$ Pantangan makanan adalah kebiasaan, budaya atau anjuran yang tidak memperbolehkan untuk mengkonsumsi jenis makanan tertentu misalnya sayuran, buah, ikan dan makanan tertentu lainnya karena dianggap dapat mempengaruhi kesehatan, khususnya bayi jika pada ibu hamil. Tampaknya berbagai pantangan tersebut pada mulanya dimaksudkan untuk menjaga kesehatan ibu dan bayi, namun tujuan ini bahkan ada yang berakibat sebaliknya yaitu merugikan 
kondisi kesehatan ibu hamil terutama masalah kecukupan nutrisinya, karena dampak pembatasan makanan yang dilakukan oleh ibu adalah kurang tercukupinya nutrisi penting pada ibu selama masa kehamilan. ${ }^{3,4}$

Hasil penelitian di Kecamatan Bangsri Kabupaten Jepara menyebutkan bahwa selama hamil, ibu biasanya akan melakukan berbagai macam upaya agar janin dan ibunya sehat dan dapat melahirkan dengan selamat, bayi yang dilahirkan normal atau tidak cacat. Hal inilah yang mendorong sebagian masyarakat untuk berpantang makan makanan tertentu seperti kepiting atau udang dan buah nenas, walaupun jika dinilai dari sudut pandang kesehatan, berpantang makan makanan tertentu bisa saja tidak dibenarkan apalagi jika makanan tersebut bergizi tinggi. ${ }^{5}$

Hasil penelitian yang lain di Kecamatan Sedayu Kabupaten Bantul menyebutkan bahwa jenis makanan pantangan pada ibu hamil terdiri dari makanan hewani seperti udang, makanan laut, belut, lele, telur boiler, jeroan, ikan asin, sarden kaleng, susu; sayuran seperti sayur mentah (lalapan), daun pepaya, pare, daun singkong, petai, buah pepaya muda, jamur, dan cabai; buah-buahan seperti buahan yang berasa asam, nangka, nanas, durian; minuman seperti minuman alkohol, minuman bersoda, teh, kopi, jamu, minuman dingin/es; dan makanan pokok seperti tape, roti, dan mie instan. Adapun alasannya adalah karena dapat membahayakan ibu hamil dan janinnya, menyebabkan zat gizi tidak bisa masuk ke janin, dapat membuat air ketuban menjadi keruh, dapat membuat gatal-gatal atau alergi, dapat membuat panas, bisa menurunkan hemoglobin $(\mathrm{Hb})$, dan dapat mempersulit pada saat melahirkan, serta bertentangan dengan ajaran leluhur dan orang tua. ${ }^{6}$

Berdasarkan uraian di atas dapat disimpulkan bahwa masih ada ibu hamil di daerah-daerah tertentu atau suku-suku tertentu yang masih melakukan pantangan makan selama masa kehamilan dengan alasan budaya. Hal ini terjadi karena banyak adat istiadat, kebiasaan, dan kepercayaan yang berhubungan dengan masalah makanan, yang mana setiap suku bangsa mempunyai cara tersendiri dalam hal memilih jenis makanan yang dimakan. Hal ini pada akhirnya dapat memberikan dampak terhadap status gizi ibu hamil, terlebih lagi jika tidak diimbangi dengan makanan pengganti. ${ }^{7,8,9}$

Salah satu suku yang masih menjalankan budaya tersebut adalah masyarakat Suku Dayak, yang mana mayoritas terdapat di pulau Kalimantan, khususnya di Kabupaten Sintang Provinsi Kalimantan Barat. Hal inilah yang mendasari peneliti untuk meneliti tentang perilaku berpantang makan pada ibu hamil Suku Dayak di Kabupaten Sintang Kalimantan Barat.

\section{METODE PENELITIAN}

Jenis penelitian yang dilakukan menggunakan pendekatan kualitatif. Penelitian ini dilakukan di wilayah Kabupaten Sintang Kalimantan Barat. Informan dalam penelitian ini berjumlah 8 orang yang terdiri dari 5 orang informan utama dan 3 orang informan triangulasi yang merupakan tokoh masyarakat dan penduduk Suku Dayak. Teknik pengambilan sampel menggunakan purposive sampling. Data diperoleh dengan menggunakan wawancara mendalam dan analisis data menggunakan analysis content.

\section{Hasil DAN PEMBAHASAN \\ Jenis Makanan yang Dipantang}

Kelompok makanan yang dipantang oleh ibu hamil terdiri dari kelompok sumber makanan pokok, lauk pauk, sayuran, buahan, dan minuman. Data selengkapnya tentang jenis makanan yang dipantang dapat dilihat pada Tabel 1. 
Tabel 1. Jenis Makanan yang Dipantang

\begin{tabular}{ll}
\hline \multicolumn{1}{c}{ Kelompok makanan } & \multicolumn{1}{c}{ Jenis Makanan } \\
\hline Makanan pokok & Ketan hitam \\
Lauk pauk & Ikan \\
& Ikan asin \\
Sayuran & Sayur rebung
\end{tabular}

\section{Alasan Berpantang dan Penganjur Untuk Berpantang}

Alasan ibu hamil berpantang makan secara umum adalah karena makanan tersebut dapat berdampak pada kesehatan ibu dan bayinya. Penganjur ibu hamil

\begin{tabular}{ll} 
& Sayur keladi \\
& Sayur nangka \\
Buah & Nanas \\
& Durian \\
& Cabe \\
Minuman & Minuman dingin atau \\
& es \\
\hline
\end{tabular}

untuk berpantang antara lain adalah orang tua / mertua, suami, dan keluarga terdekat / kerabat. Data selengkapnya tentang alasan berpantang makan dan penganjur untuk berpantang dapat dilihat pada Tabel 2 .

Tabel 2. Alasan Berpantang dan Penganjur Untuk Berpantang

\begin{tabular}{|c|c|c|c|}
\hline Kelompok & Jenis Makanan & Alasan & Penganjur \\
\hline Makanan pokok & Ketan hitam & Menyebabkan sakit pinggang. & Orang tua/mertua \\
\hline \multirow[t]{2}{*}{ Lauk pauk } & Ikan & Menyebabkan air susu berbau amis & Suami \\
\hline & Ikan asin & $\begin{array}{l}\text { Menyebabkan bayi gatal-gatal dan tidak } \\
\text { bagus untuk kulit bayi }\end{array}$ & Keluarga/kerabat \\
\hline \multirow[t]{2}{*}{ Sayuran } & $\begin{array}{l}\text { Sayur rebung } \\
\text { Sayur keladi }\end{array}$ & $\begin{array}{l}\text { Menyebabkan gatal-gatal pada ibu dan } \\
\text { bayi }\end{array}$ & \\
\hline & Sayur nangka & Menyebabkan gatal-gatal pada ibu dan & \\
\hline \multirow[t]{4}{*}{ Buahan } & Nanas & bayi & \\
\hline & Durian & Mengurangi produksi ASI & \\
\hline & Cabe & Menyebabkan keguguran & \\
\hline & & Menyebabkan keguguran dan perdarahan & \\
\hline \multirow[t]{3}{*}{ Minuman } & Es & Menyebabkan perut ibu menjadi panas dan & \\
\hline & & kulit bayi menjadi merah-merah & \\
\hline & & $\begin{array}{l}\text { Menyebabkan ukuran bayi menjadi besar } \\
\text { dan mempersulit proses kelahiran }\end{array}$ & \\
\hline
\end{tabular}

Alasan ibu hamil berpantang makan

ketan hitam karena dapat menyebabkan sakit pinggang.

Memang kame' larang dia makan ketan hitam tu buk ... bukan apa, nantik sakit pinggang pulak

Takutnya sakit pinggang kak kalau makan ketan hitam tu

Ketan hitam merupakan salah satu sumber karbohidrat yang cukup tinggi. Selain itu, ketan hitam juga memiliki kandungan lemak yang rendah dan kaya akan serat yang baik bagi pencernaan. ${ }^{1}$

Ikan tu kan kuat amisnya ba ... apalagi kalau masaknya direbus, takutnya aek susunya nanti pas melahirkan jadi bau amis

Mertua ku bilang kalau pas hamil sampai melahirkan nanti ... jangan dulu makan ikan, nanti aek susunya amis
Alasan ibu hamil berpantang makan ikan karena dapat menyebabkan air susu berbau amis. Ikan merupakan bahan makanan sumber protein yang cukup potensial dan dapat dibandingkan atau disejajarkan dengan bahan makanan hewani lainnya seperti daging sapi, unggas, telur, dan susu. Kandungan gizi penting pada ikan yang sangat berperan didalam menjaga kesehatan tubuh adalah asam lemak omega 3. Di samping itu, ikan juga merupakan sumber gizi mineral yang sangat penting yaitu kalsium, fosfor dan zat besi. ${ }^{1}$

Mengkonsumsi ikan asin secara tidak berlebihan merupakan hal yang dianjurkan karena di dalam ikan asin terkandung zat 
gizi seperti lemak, zat besi yang berguna untuk memproduksi sel darah merah di dalam tubuh, serta yodium. ${ }^{1}$

Alasan ibu hamil berpantang makan ikan asin karena tidak bagus untuk kulit bayi dan dapat menyebabkan gatal-gatal pada bayi yang dilahirkan.

Nanti kulit bayinya gatal-gatal buk ... mertuaku yang bilang

Selama hamil ni ... ndak berani kame' makan ikan asin, benda tu kan kuat asinnya, ndak bagus nanti untuk kulit bayi

Alasan ibu hamil berpantang makan sayur rebung karena dapat menyebabkan gatal-gatal pada ibu dan bayi.

Rebung tu kan gatal ba kak ... nanti badan anak juga gatal-gatal, jadi dengan suamiku dilarang dulu makan itu

Takut nanti umak dengan anak gatal-gatal ba kalau makan rebung tu ...

Rebung merupakan makanan yang rendah glukosa, mengandung protein, dan kaya akan vitamin dan mineral. Vitamin yang terkandung dalam rebung antra lain vitamin $\mathrm{A}$, vitamin $\mathrm{B} 6$, vitamin $\mathrm{E}$, thiamin, riboflavin, niasin, asam folat, dan asam pantotenat, sedangkan kandungan mineralnya meliputi kalsium, magnesium, seng, tembaga, mangan, selenium dan zat besi. ${ }^{1}$

Alasan ibu hamil berpantang makan sayur keladi karena dapat menyebabkan gatal-gatal pada ibu dan bayi.

Umak kame' dulu pernah bilang kalau makan keladi pas lagi hamil tu bisa nyebabkan gatalgatal

Keladi tu sama dengan rebung ... bisa buat gatalgatal
Keladi atau talas merupakan sumber karbohidrat dan memiliki jumlah serat tiga kali lipat dibandingkan dengan kentang putih. Selain itu, keladi atau talas juga memiliki kandungan protein, zat besi, vitamin $\mathrm{C}$, dan vitamin $\mathrm{A} .{ }^{1}$

Alasan ibu hamil berpantang makan sayur nangka karena dapat mengurangi produksi air susu setelah melahirkan

Takutnya aek susu nanti jadi ndak banyak keluarnya buk ...

Nangka tu kan banyak getahnya ba ... nanti aek susu ibuknya sikit jak jadinya kalau pas dah melahirkan

Kalori yang terkandung di dalam nangka muda dua kali lebih rendah diandingkan dengan nangka masak. Selain itu, nangka muda juga memiliki kandungan mineral seperti kalsium dan fosfor, juga vitamin seperti vitamin A dan vitamin $\mathrm{C}$. Namun, nangka muda mengandung sedikit nutrisi jika dibandingkan dengan sayuran hijau lainnya. Oleh karena itu sebaiknya nangka muda diolah bersama sayuran lainnya. ${ }^{1}$

Alasan ibu hamil berpantang makan nanas karena dapat menyebabkan keguguran.

Kalau kata orang tua dulu ... buah tu tajam, nanti bisa keguguran kalau makan buah itu ...

Ndak berani kame' makan buah itu kak .... takut keguguran

Mengkonsumsi buah nanas saat hamil dalam porsi secukupnya tidak membawa dampak buruk pada kehamilan, karena jumlah kandungan enzim bromelain (yang diduga dapat menyebabkan perdarahan dan keguguran) pada nanas segar terlalu kecil untuk memiliki efek pada rahim dan sistem reproduksi. Buah nanas banyak mengandung vitamin $\mathrm{C}$ dan vitamin serta mineral lainnya seperti 
vitamin A dan B6, folat, zat besi, magnesium, kalium, dan mangan. ${ }^{1}$

Alasan ibu hamil berpantang makan durian karena dapat menyebabkan perdarahan saat hamil dan keguguran

Kalau lagi hamil tahan-tahan jak dulu jangan makan buah itu ... apalagi sekarang agik musim, bise-bise keguguran

Kame' dilarang makan buah itu ... takutnya nant bisa perdarahan. Suami dan mertuaku duaduanya ndak bolehkan

(IP 5)

Mengkonsumsi durian dalam jumlah yang tidak berlebihan pada ibu hamil tidaklah membahayakan kehamilan karena selain memiliki kandungan karbohidrat dan serat yang cukup tinggi, buah durian juga memiliki kandungan protein, vitamin $\mathrm{C}$ dan vitamin $B$, serta mineral. ${ }^{1}$

Alasan ibu hamil berpantang makan cabe karena dapat menyebabkan perut menjadi panas dan kulit bayi menjadi merah-merah.

Cabe tu bisa buat perut panas kak ... kasian bayinya

Makanan yang pedas tidak akan membahayakan perkembangan janin di dalam kandungan, namun bisa mempengaruhi kondisi ibu hamil karena makan makanan pedas yang berlebihan dapat menyebabkan iritasi pada lambung. Cabe atau cabai memiliki kandungan vitamin $C$ yang sangat tinggi. Selain itu, cabe atau cabai juga memiliki kandungan vitamin $\mathrm{A}$, vitamin $\mathrm{B}$, dan vitamin $\mathrm{E}$, serta memiliki kandungan mineral seperti magnesium, kalium, folat, dan mangan. ${ }^{1}$

Kalau yang suka makan cabe tu ... pas hamil tahan-tahan lok, kasian nanti kalau lahir kulit bayinya merah-merah, karna cabe tu panas ba ...

(IP 7)

Alasan ibu hamil berpantang makan es karena dapat menyebabkan berat badan bayi menjadi besar dan dapat mempersulit pada saat melahirkan. Kebutuhan akan cairan sangat penting untuk menjaga kesehatan ibu hamil dan janin di dalam kandungan, terlepas dari meminum air es atau air hangat. Air es yang membuat bayi menjadi besar adalah apabila dicampur dengan bahan makanan yang mengandung glukosa tinggi seperti gula atau sirup, karena makanan atau minuman dengan glukosa tinggi secara berlebihan bisa membuat janin menjadi berukuran besar.

Itu tu bisa buat jalan lahir jadi sempit, jadi susah pas mau melahirkan ... lama nanti nyakitkannya ba ...

Kata umak kame' nanti bayinya besar kalau banyak minum es ...

Jenis makanan yang paling banyak dipantang oleh ibu hamil adalah ikan. Data selengkapnya tentang jumlah jenis makanan yang dipantang dapat dilihat pada Gambar 1.

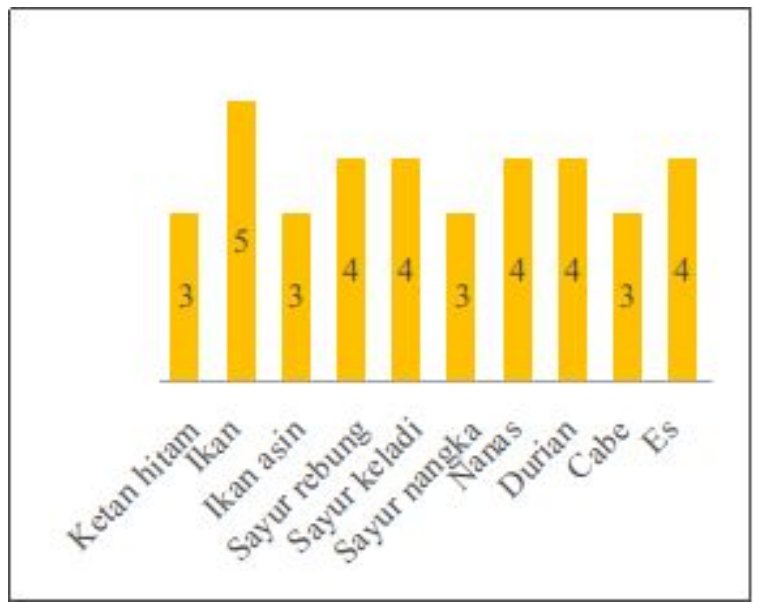

\section{Gambar 1. Jumlah Jenis Makanan yang Dipantang}

Hasil penelitian di Kabupaten Grobogan Jawa Tengah menyatakan bahwa ada pengaruh tabu makan dengan angka kejadian anemia pada ibu hamil Trimester II dengan tingkat signifikansi atau $p$ value $0,47(<0,05) .{ }^{10}$ Penelitian lain di Kabupaten Jepara menyatakan bahwa ada hubungan antara budaya pantang 
makan dengan status gizi pada ibu hamil Trimester III $(p=0,002 ; \alpha=0,05){ }^{11}$

Hasil penelitian lain di Kota Pekalongan menyatakan bahwa dari hasil uji regresi menunjukkan tabu makanan, tingkat kecukupan protein, zat besi, vitamin $\mathrm{C}$ dan konsumsi tablet besi serta kebiasaan minum teh secara bersama-sama mempengaruhi kadar $\mathrm{Hb}$ ibu hamil $(\mathrm{p}<$ 0,05), kontribusi terbesar adalah tabu makanan $\mathrm{R}$ square $=0,599 .{ }^{12}$

Penelitian di Ghana menunjukkan bahwa ibu hamil sebenarnya telah memahami bahwa pantangan untuk konsumsi makanan tertentu sebenarnya disebabkan kepercayaan orang tua, mertua atau tokoh masyarakat sekitar. Hanya saja, para ibu hamil tetap mematuhi larangan konsumsi makanan tersebut untuk menghormati orang tua, tokoh masyarakat dan para tetua di masyarakat. ${ }^{13}$

Namun penelitian lain di Kecamatan Sedayu Kabupaten Bantul Yogyakarta menyatakan bahwa pantang makan tidak mempunyai hubungan yang signifikan terhadap kejadian KEK dengan nilai $\mathrm{p}=$ $0,44(>0,05) \cdot{ }^{13}$

\section{KESIMPULAN}

Masih ditemukan sejumlah bahan makanan yang dipantang oleh ibu hamil dengan alasan untuk kesehatan ibu dan bayinya, walaupun jenis makanan yang dipantang tersebut bertolak belakang dengan prinsip ilmu gizi. Untuk peneliti selanjutnya diharapkan ada kajian yang lebih lanjut terhadap kandungan zat gizi yang ada di dalam jenis makanan yang menjadi pantangan makanan ibu hamil. Peneliti mengucapkan terimakasih yang sebesar-besarnya kepada masyarakat Suku Dayak yang terlibat dalam penelitian ini.

\section{DAFTAR PUSTAKA}

1. Irianto, K. Gizi Seimbang dalam Kesehatan Reproduksi. Bandung: CV. Alfabeta; 2014.

2. Paath, E. F., Rumdasih, Y., Heryati. Gizi dalam Kesehatan Reproduksi. Jakarta: EGC; 2005.
3. Khasanah, N. Dampak Persepsi Budaya Terhadap Kesehatan Reproduksi Ibu dan Anak di Indonesia. Muwazah. 2011; 3(2): 487-492.

4. Purwoastuti, E dan Walyani, E. S. Pokok-Pokok Ilmu Sosial dan Budaya Dasar Pada Kebidanan. Yogyakarta: Pustakabarupress; 2015.

5. Suryawati, C. Faktor Sosial Budaya dalam Praktik Perawatan Kehamilan, Persalinan dan Pasca Persalinan (Studi di Kecamatan Bangsri Kabupaten Jepara). Jurnal Promosi Kesehatan Indonesia. 2007; 2(1): 21-31.

6. Oktriyani., Juffrie, M., Astiti, D. Pola Makan dan Pantangan Makan Tidak Berhubungan Dengan Kekurangan Energi Kronis Pada Ibu Hamil. Jurnal Gizi dan Dietetik Indonesia. 2014; 2(3): 159-169.

7. Oni O, Tukur. Identifying Pregnant Women Who Would Adhere to Food Taboos in a Rural Community: a Community-Based Study. Journal Reprod Health. 2012; 16(3).

8. Lee, D., et al. Antenatal Taboos Among Chinese Women in Hong Kong. Scienedirect Midwifeny. 2009; 25: 104-13.

9. Alwi, Q. Tema Budaya yang Melatarbelakangi Perilaku Ibu-Ibu Penduduk Asli Dalam Pemeliharaan Kehamilan dan Persalinan di Kabupaten Mimika. Buletin Penelitian Kesehatan. 2007; 35(3); 137-47.

10. Martini, S. dan Haryanti, T. Pengaruh Tabu Makan Terhadap Angka Kejadian Anemia Pada Ibu Hamil Trimester II. Jurnal Kesehatan Ibu dan Anak Akademi Kebidanan An-Nur. 2016; 1( 1).

11. Susanti, A., Rustono., dan Asiyah, N. Budaya Pantang Makan, Status Ekonomi, dan Pengetahuan Zat Gizi Ibu Hamil Pada Ibu Hamil Trimester III Dengan Status Gizi. JIKK. 2013; 4(1): 1-9.

12. Harnany, A. S. Pengaruh Tabu Makan, Tingkat Kecukupan Gizi, Konsumsi 
Tablet Besi, dan Teh Terhadap Kadar Hemoglobin Pada Ibu Hamil Di Kota Pekalongan (Tesis). Semarang: Universitas Diponegoro; 2006.

13. Arzoaquoi, S.K., Essuman, E.E., Gbagbo, F.Y. et al. 2015. Motivations for food prohibitions during pregnancy and their enforcement mechanisms in a rural Ghanaian district. $J$ Ethnobiology Ethnomedicine 11 (59)

14. Oktriyani., Juffrie, M., Astiti, D. Pola Makan dan Pantangan Makan Tidak Berhubungan Dengan Kekurangan Energi Kronis Pada Ibu Hamil. Jurnal Gizi dan Dietetik Indonesia. 2014; 2( 3): 159-169. 